\title{
ІНФОРМАЦІЙНЕ ЗАБЕЗПЕЧЕННЯ СТРАТЕГІЇ ВИЗНАЧЕННЯ ОПТИМАЛЬНОЇ ТАКТИКИ ХІРУРГІЧНОГО ЛІКУВАННЯ ХВОРИХ 3 ПРОЛІФЕРАТИВНОЮ ДІАБЕТИЧНОЮ РЕТИНОПАТІЄЮ
}

\author{
Національна медична академія післядипломної освіти імені П. А. Шупика \\ У статті представлено оцінювання прогностичної цінності факторів ризику, які впливають на результат хірургічно- \\ го втручання у хворих з проліферативною діабетичною ретинопатією.
}

Ключові слова: інформаційна модель, визначення оптимальної тактики, прогнозування результату, вітректомія, проліферативна діабетична ретинопатія.

\section{ИНФОРМАЦИОННОЕ ОБЕСПЕЧЕНИЕ СТРАТЕГИИ ОПРЕДЕЛЕНИЯ ОПТИМАЛЬНОЙ ТАКТИКИ ХИРУРГИЧЕСКОГО ЛЕЧЕНИЯ ПАЦИЕНТОВ С ПРОЛИФЕРАТИВНОЙ ДИАБЕТИЧЕСКОЙ РЕТИНОПАТИЕЙ}

А. Н. Рубан

Национальная медицинская академия последипломного образования имени П. А. Шупика

В статье представлено оценивание прогностической ценности факторов риска, влияющих на результат хирургического лечения пациентов с диабетической пролиферативной ретинопатией.

Ключевые слова: информационная модель, прогнозирование результата, витректомия, пролиферативная диабетическая ретинопатия.

\section{INFORMATION SUPPORT IN DETECTION OF OPTIMAL TACTICS DEALING WITH THE SURGICAL TREATMENT OF THE PATIENTS WITH PROLIFERATIVE DIABETIC RETINOPATHY}

\section{A. M. Ruban}

National Medical Academy of Post-Graduate Education by P. L. Shupyk

\begin{abstract}
The article describes the information model in detection of any factors that may predict visual outcome after vitrectomy for proliferative diabetic retinopathy.
\end{abstract}

Key words: information model, predictive factors, vitrectomy, proliferative diabetic retinopathy.

Вступ. За останні десятиріччя цукровий діабет (I ІД) став однією з найважливіших медико-соціальних проблем, у зв'язку з високим рівнем інвалідизації та летальності. Внаслідок старіння населення, підвищення рівня ожиріння, гіподинамії, вживання рафінованої їжі до 2025 року в світі цукровим діабетом, за оцінками експертів ВООЗ, будуть страждати понад 300 млн людей [1].

Найбільш поширеним мікроваскулярним ускладненням цукрового діабету є діабетична ретинопатія [2]. Кількість пацієнтів із діабетичною ретинопатією у 2050 році, як очікують, збільшиться втричі [3]. За оцінками дослідників, 97 \% пацієнтів з інсулінзалеж- ним типом (I3Т) цукрового діабету та 80 \% з інсуліннезалежним типом (IHЗТ) діабету, при тривалості захворювання більше 15 років мають ознаки діабетичної ретинопатії. Близько 40 \% пацієнтів з ІЗТ та 5 \% пацієнтів з IНЗТ мають ознаки проліферативної діабетичної ретинопатії (ПДР) [4].

Проліферативна діабетична ретинопатія $€$ кінцевою та найбільш небезпечною стадією діабетичної мікроангіопатії. Зниження зору при ПДР трапляється внаслідок інтравітреального крововиливу, макулярного набряку, тракційного або регматогеного відшарування сітківки, неоваскулярної глаукоми [5]. 
Вітректомія, як метод хірургічного лікування ускладнень ПДР, був впроваджений в клінічну практику 40 років тому, але і на сучасному етапі є «золотим стандартом» в лікуванні цієї складної патології [6]. Використання бімануальної малоінвазивної хірургії, ендолазерної коагуляції, ширококутових офтальмоскопічних систем, мультипортової ілюмінації [7], впровадження перфторкарбонових рідин, силіконової олії [8] забезпечили вітреоретинальному хірургу ефективну технічну підтримку за останні роки [9]. Стабілізація або покращення зорових функцій після вітректомії досягається у 67-86 \% хворих [10]. Між тим, результат оперативного втручання є не завжди прогнозованим і залежить від багатьох доопераційних, інтраопераційних та післяопераційних факторів. Серед них найбільш важливими є соматичний стан хворого, тяжкість офтальмологічного статусу, особливості хірургічної техніки та післяопераційні ускладнення [11]. Серед фахівців немає чіткого уявлення про найбільш важливі прогностичні чинники та вірогідні виходи операції, що робить неможливим на сьогоднішній день прогнозування післяопераційної гостроти зору.

Отже, враховуючи недостатній і заперечливий характер існуючих даних, стає надзвичайно актуальним визначення й оцінювання впливу різноманітних факторів ризику на кінцевий функціональний результат оперативного лікування пацієнтів $з$ проліферативною діабетичною ретинопатією.

Мета роботи: оцінювання прогностичної цінності факторів ризику при хірургічному втручанні у хворих з проліферативною діабетичною ретинопатією.

Матеріали та методи досліджень. Були виділені 6 груп клінічних показників, які можна розглядати як фактори ризику. Для визначення прогностичної значущості цих показників розроблена спеціальна карта. Кожен блок карти має наскрізне кодування, що дозволяє полегшити внесення інформації до комп'ютера. Для забезпечення єдиної інтерпретації кожен показник має уніфіковані градації. Наприклад:

Внутрішньоочний тиск (пневмотонометрія):

нормотонія (11 - 23 мм рт.ст.) - 1;

гіпертонія (>24 мм рт.ст) - 2;

гіпотонія (<10 мм рт.ст.) - 3 .

В карту внесені клінічні показники, що потенційно можуть бути факторами ризику при хірургічному лікуванні хворих з проліферативною діабетичною ретинопатією.

При цьому звертали увагу на проблему стандартизації інформації. Особливо гостро стоїть проблема багатозначності понять в предметних галузях, що швидко розвиваються, до яких і належить офтальмологія.

Зазначимо, що для розв'язання проблеми стандартизації термінів і понять існує ряд основних нормативних документів, що регламентують створення систем термінологічних стандартів і тлумачних словників.

Базовим поняттям вказаних документів є поняття "гармонізація". При цьому гармонізація власне понять визначається як цілеспрямована діяльність, що дозволяє усунути чи знизити до прийнятного рівня відміни, які відносяться до різних поняттєвих систем, що описують один і той самий об' єкт стандартизації. Це визначення наводиться в документах ICO/TК 37.

\section{Результати та їх обговорення.}

Аналіз доопераційних соматичних факторів. За результатами клінічних досліджень відомо, що такі доопераційні системні чинники, як наявність діабетичної нефропатії, гіпертензія, анемія, вік пацієнта, тривалість діабету, інсулінотерапія та схильність до гіперкоагуляції можуть мати суттєве негативне значення для прогресування діабетичної проліферативної ретинопатії $[13,14]$. Разом з тим, в сучасній літературі є достовірні дані, які свідчать, що підтримання стійкої компенсації цукрового діабету може значно затримати (на 40-60 \%) розвиток ретинопатії. Своєчасно встановлений діагноз та правильне лікування можуть запобігти розвитку сліпоти більш ніж у 50 \% пацієнтів [15]. Для визначення найбільш важливих чинників ми визначили 24 показники, які відображають соматичний стан пацієнта. Вони обрані серед кластерів анкетування, вимірювання АТ, біохімічних показників тощо. Попередньо всі дані вносилися в анкету. Для кожного пацієнта записувались наступні системні доопераційні чинники: вік на момент операції, наявність компенсації цукрового діабету, стать, тип цукрового діабету, добова дозу інсуліну, тривалість цукрового діабету, наявність гіпоглікемії, енцефалопатії, інсульту, інфаркту міокарда, ішемічної хвороби серця, гіпертонічної хвороби, ниркової недостатності, ампутації, переміжної кульгавості, некрозу пальця, втрати чутливості кінцівок, набряків кінцівок, трофічних виразок, глюкозурії, ацетонурії, альбумінурії, концентрація гемоглобіну, глюкози крові. Результати біохімічних досліджень використовувались за даними аналізів, зібраних пацієнтом для госпіталізації в стаціонар. Гіпертензія діагностувалась при наявності анамнезу та діастолічного кров'яного тиску більше 95 шш Ниркова недостатність діагностувалась при концентрації креатиніну плазми більше 150 мкммоль/л.

Аналіз доопераційних офтальмологічних чинників. Обстеження пацієнтів відбувалося з викорис- 
танням стандартних методів офтальмологічного обстеження і включало опитування з уточненням скарг і анамнезу, перевірку гостроти зору (візометрія), вимірювання поля зору (періметрія), тонометрію, біомікроскопію, зворотну офтальмоскопію, флуоресцентну ангіографію, оптичну когерентну томографію, фотографію очного дна, ультразвукове сканування. Вважаємо за необхідне вивчити прогностичну значимість 33 факторів (табл. 1), що відображають стан ока пацієнта до операції. Серед факторів особливу увагу приділяли тим, які характеризують анатомічний та функціональний стан центральної сітківки (гострота зору, наявність і тип відшарування сітківки) та ступінь прояву ішемії сітківки (неоваскуляризація сітківки, райдужки, неоваскулярна глаукома). Актуальність вивчення саме цих факторів неодноразово підкреслювали Smiddy, Flynn, Thompson, та інші, які вважали важливими доопераційними факторами ризику важкої втрати зору доопераційну гостроту зору <5/200, наявність неоваскуляризації райдужки, неоваскулярну глаукому та відшарування сітківки $[16,17]$.

Таблиця 1. Перелік показників для аналізу прогностичної інформативності.

Офтальмологічні доопераційні фактори

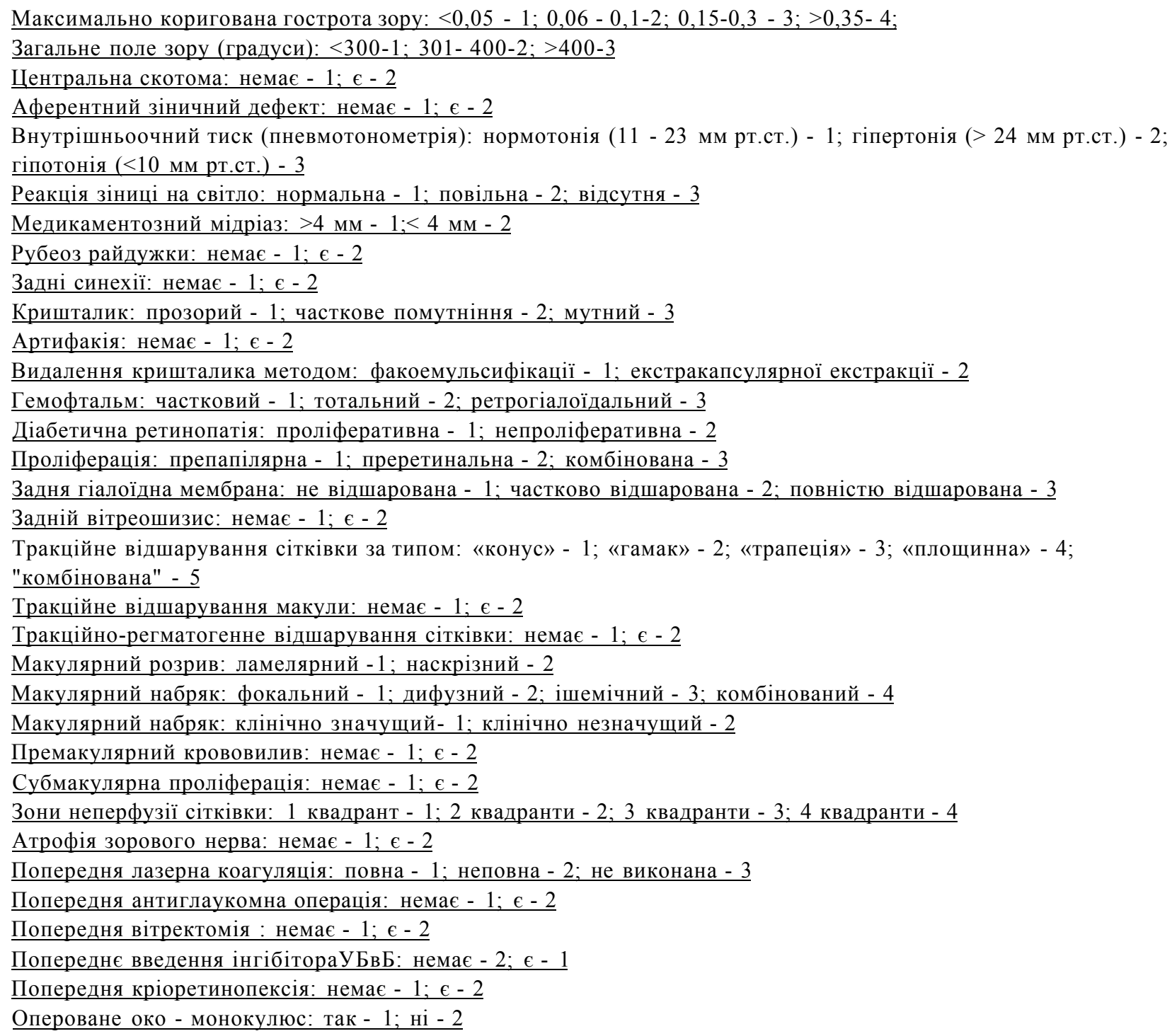

Для визначення гостроти зору між 1,0 та 0,05 ми використовували таблицю Сивцева - Головіна, а саме:

1) максимально коригована гострота зору (МКГЗ) на останньому огляді;
2) відсоток пацієнтів з покращенням зору > 1 рядка в порівнянні з доопераційним зором;

3) відсоток пацієнтів зі стабільним зором (зміни гостроти зору в межах одного рядка); 
4) відсоток пацієнтів зі зниженням гостроти зору > 1 рядків в порівнянні з доопераційним зором;

5) відсоток пацієнтів з незадовільним функціональним результатом (гострота зору $<0,1$ ).

Макулярна ішемія визначалась як збільшення фовеолярної аваскулярної зони (ФАЗ) за результатами флуоресцентної ангіографії.

Аналіз інтраопераційних чинників. За даними Okamoto та Davis $[18,19]$ особливості інтраопераційної техніки є одними з найбільш важливих чинників, що впливають на кінцевий функціональний результат хірургічного лікування діабетичних хворих. Для виз- начення найбільш суттєвих прогностичних чинників незадовільного результату вітректомії нами проаналізовано 27 факторів, що відображають особливості проведеної операції (табл. 2).

Особливу увагу приділяли вивченню прогностичної ролі найбільш сучасних вітреоретинальних технологій (малоінвазивна 230 та 250 вітректомія, видалення внутрішньої межової мембрани, бімануальна хірургія, інтравітреальне введення інгібіторів ендотеліального фактора роста (УБОР), комбінована хірургія переднього та заднього відрізків, ендотампонада силіконовою олією, перфторорганічними сполуками.

Таблиця 2. Перелік показників для аналізу прогностичної інформативності. Інтраопераційні фактори

Вітректомія: $20 \mathrm{G}-1 ; 23 \mathrm{G}-2 ; 25 \mathrm{G}-3$

Техніка видалення мембран: деламінація мембран - 1; сегментація мембран - 2; деламінація-сегментація мембран - 3; висічення мембран блоком - 4

Видалення фіброваскулярних мембран: повне - 1 ; неповне - 2

Хірургічна техніка : бімануальна - 1 ; мономануальна - 2

Видалення фіброваскулярних мембран від ДЗН: повне - 1 ; неповне - 2

Гідростатичний гемостаз: $<1$ хв $-1 ;>1$ хв - 2

Ендодіатермія: виконувалась - 1; ні - 2

Ендолазерокоагуляція: повна - 1; неповна - 2; не проводилась - 3

Тип лазера: аргон - 1 ; діод - 2

Кріоретинопексія: виконувалась - 1 ; ні - 2

Видалення внутрішньої межової мембрани: виконувалось - 1 ; ні - 2

Видалення периферії склоподібного тіла при склеродепресії: виконувалось - 1; ні - 2

Одночасна факоемульсифікація катаракти з імплантацією ІОЛ: виконувалась - 1 ; ні - 2

Задня капсулектомія: виконувалась - 1 ; ні - 2

Інтравітреальне введення інгібітора VEGF: виконувалось - 1 ; ні - 2

Інтравітреальне введення тріамцинолону: виконувалось - $1 ;$ ні - 2

Дренуюча ретинотомія: виконувалась - 1; ні - 2

Релаксуюча ретинотомія: виконувалась - 1 ; ні - 2

Ендотампонада повітрям: виконувалась - 1; ні - 2

Тимчасова тампонада перфтордекаліном: виконувалась - 1 ; ні - 2

Ендотампонада SF6: виконувалась - 1; ні - 2

Ендотампонада С3F8: виконувалась - 1; ні - 2

Ендотампонада легким силіконом 1000 сСт: виконувалась - 1 ; ні - 2

Ендотампонада легким силіконом 5700 сСт: виконувалась - 1 ; ні - 2

Ендотампонада важким сіліконом: виконувалась - 1; ні - 2

Тривалість операції: $<1$ години - $1 ;>1$ години - 2

Іригаційний розчин: BSS - 1; BSSPlus - 2; Ringer - 3

Аналіз інтраопераційних ускладнень. Проведення хірургічного втручання завжди пов'язане з ризиками інтраопераційних ускладнень, які можуть варіювати від незначних (схильних до самовідновлення) до тяжких, що можуть призвести до незадовільного функціонального результату операції (Ishida, 2002).

Нами проаналізовано 12 найбільш статистично поширених інтраопераційних ускладнень, які, на нашу думку, можуть вплинути на кінцевий результат операції (табл. 3).

Аналіз ранніх (до 1 місячя) післяопераційних ускладнень. Більшість незадовільних результатів хірургіч- ного лікування автори напряму пов'язують з поствітректомічними ускладненнями $[20,21]$. Так, за даними $B$. ТвШвn [22], такі післяопераційні ускладнення, як рецидивуючий вітреальний крововилив, тракційне або комбіноване тракційно/регматогенне відшарування сітківки, неоваскуляризація райдужки та неоваскулярна глаукома можуть призвести до значної втрати зору. 3 метою визначення впливу ранніх післяопераційних ускладнень на кінцевий функціональній результат вітректомії у пацієнтів 3 проліферативною ретинопатією нами було проаналізовано 23 найбільш статистично поширених ускладнення, що трапились протягом 1 місяця після операції (табл. 4). 
Таблиця 3. Перелік показників для аналізу прогностичної інформативності. Інтраопераційні ускладнення

Профузний крововилив: немає - $1 ; \epsilon-2$

Ятрогенний розрив сітківки: немає - $1 ; \epsilon-2$

Розрив капсульного мішка: немає - $1 ; \epsilon-2$

Пошкодження зорового нерва: немає - $1 ; \epsilon-2$

Неадекватний мідріаз: немає - $1 ; \epsilon-2$

Ішемія сітківки: немає - $1 ; \epsilon-2$

Субретинальний крововилив: немає - $1 ; \epsilon-2$

Субретинальне попадання перфтордекаліну: немає - 1; є - 2

Макулярний розрив: немає - $1 ; \epsilon-2$

Пошкодження райдужки: немає - $1 ; \epsilon-2$

Супрахоріӧдальне попадання іригаційного розчину: немає - $1 ; \epsilon-2$

Пошкодження кришталика: немає - 1;є - 2

Таблиця 4. Перелік показників для аналізу прогностичної інформативності. Ранні післяопераційні ускладнення (до 1 міс.)

Інтравітреальний крововилив: немає - $1 ; \epsilon-2$

Підвищення внутрішньоочного тиску: немає - $1 ; \epsilon-2$

Зниження внутрішньоочного тиску: немає - 1; $\epsilon-2$

Регматогенне відшарування сітківки: немає - $1 ; \epsilon-2$

Преретинальний крововилив (під силіконом) : немає - $1 ; \epsilon-2$

Фібрин-синдром: немає - $1 ; \epsilon-2$

Тракційне відшарування сітківки: немає - $1 ; \epsilon-2$

Макулярний набряк: немає - $1 ; \epsilon-2$

Субретинальний крововилив: немає - $1 ; \epsilon-2$

Репроліферація: немає - $1 ; \epsilon-2$

Помутніння кришталика: немає - $1 ; \epsilon-2$

Задні синехії: немає - 1; $є-2$

Фіброз задньої капсули: немає - $1 ; \epsilon-2$

Неоваскуляризація сітківки: немає - $1 ; \epsilon-2$

Неоваскулярна глаукома: немає - $1 ; \epsilon-2$

Субретинальний силікон: немає - $1 ; \epsilon-2$

Передня гіалоїдна проліферація: немає - $1 ; \epsilon-2$

Передня ішемічна оптична нейропатія: немає - $1 ; \epsilon-2$

Атрофія зорового нерва: немає - $1 ; \epsilon-2$

Емульгація силікону: немає - 1; є-2

Іридоцикліт: немає - $1 ; \epsilon-2$

Кератопатія: немає $-1 ; \epsilon-2$

Ендофтальміт: немає - $1 ; \epsilon-2$

Аналіз пізніх післяопераційних ускладнень (від 1 до бмісяиів). В опублікованих раніше роботах автори відносять до пізніх післяоперативних факторів ризику значне погіршення зору після вітректомії: оптичну або макулярну ішемію та атрофію [24, 25, 26, 27], хронічний дифузний макулярний набряк [28], післяопераційне відшарування сітківки, доопераційну неоваскуляризацію райдужки, неоваскулярну глаукому, рецидивуючий гемофтальм, фіброваскулярну проліферацію [29, 30, 31].

Загалом нами вивчався вплив 25 найбільш поширених пізніх післяопераційних ускладнень на несприятливий кінцевий результат оперативного втручання пацієнтів з ПДР (табл. 5).
Отже, комплексний план вивчення факторів ризику виникнення ускладнень при проліферативній діабетичній ретинопатії сумарно складає 145 показників. Така велика кількість показників ще раз підкреслює необхідність вивчення важливості кожного з них, стиснення інформації, виявлення комплексних факторів ризику. Показники, що пропонуються для детального аналізу, наведені в таблиці 1.

Зауважимо, що математичний аналіз вельми залежить від кількості показників, що пропонуються для оброблення. Тому детальне обговорення на попередньому етапі вкрай необхідне. 
Таблиця 5. Перелік показників для аналізу прогностичної інформативності.

Пізні післяопераційні ускладнення (>1 міс.)

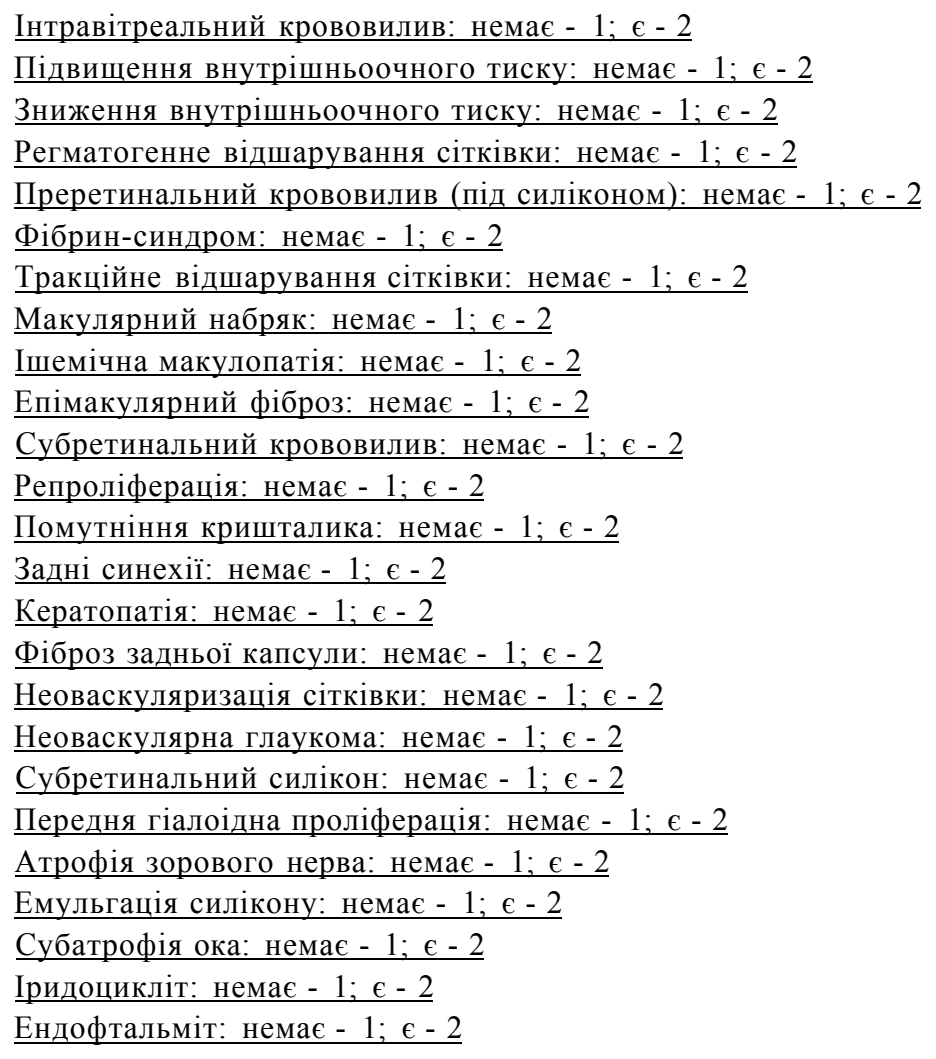

Висновки. 1. Підвищення якості хірургічного втручання та післяопераційного ведення пацієнтів 3 проліферативною діабетичною ретинопатією залежить від детального вивчення факторів ризику несприятливого розвитку хвороби.

\section{Література}

1. Global prevalence of diabetes: estimates for the year 2000 and projections for 2030 / S. Wild, G. Roglic, A. Green, [et al.] / / Diabetes Care. - 2004. - Vol. 27. - P. 1047-1053.

2. The epidemiology of ocular problems in diabetes mellitus. In: Feman SS, ed. Ocular Problems in Diabetes Mellitus / Klein R., B. E. K. Klein, S. E. Moss // St. Louis: CV Mosby Co. - 1989. -P255-264.

3. Prevalence and risk factors for diabetic retinopathy. The Singapore Malay eye study / T. Y. Wong, N. Cheung, W. T. Tay [et al.] // Ophthalmology. -2008. - Vol. 115. - P. 1869-1875. 4. Jochmann C. Epidemiology, pathogenesis and therapy of diabetic retinopathy and maculopathy / C. Jochmann, H. P. Hammes // Z. Arztl. Fortbild. Qualitatssich. - 2002. - Vol. 96. - P. 167-174.

5. Mohamed Q. Management of diabetic retinopathy: a systematic review / Q. Mohamed, M. C. Gillies, T. Y. Wong// JAMA. - 2007. - Vol. 298. - 902-916

6. Vitrectomy in the management of diabetic retinopathy / W. E. Smiddy, H. W. Jr. Flynn// Surv. Ophthalmol. - 1999. - Vol. 43. - P. 491-507.
2. Основним завданням в проблемі покращання результатів вітректомії при проліферативній діабетичній ретинопатії слід вважати визначення факторів ризику незадовільного результату операції та методів профілактики їх виникнення.

7. Steinmetz R. L. Vitrectomy for diabetic tration retinal detachment using the multiport illumination system / R. L. Steinmetz, S. Grizzard, M. E. Hammer Ophthalmology. -2002. Vol. 109. - P. 2303-2307.

8. Vitrectomy with silicone oil infusion in severe diabetic retinopathy / A. Castellarin, R. Grigorian, N. Bhagat [et al.] // Br. J. Ophthalmol. - 2003. - Vol. 87. - P. 318-321.

9. Abrams G. W. "En bloc" excision of diabetic membranes / Abrams G. W., Williams G. A. // Am. J. Ophthalmol. -1987. 103. - Vol. 302-308.

10. Recent outcomes of vitreous surgery for diabetic retinopathy / H. Oda, K. Konno, K. Mitsui [et al.] // Nippon Ganka Gakkai Zasshi. - 2005. - Vol. 109. - P. 603-612.

11. Causes of severe visual loss in the early treatment diabetic retinopathy study: ETDRS report no. 24. Early Treatment Diabetic Retinopathy Study Research Group / D. S. Fong, F. L. Ferris, III, M. D. Davis, E. Y Chew // Am. J. Ophthalmol. - 1999. - Vol. 127. - P. 137-141.

12. Kakehashi A. Total en bloc excision: a modified vitrectomy 
technique for proliferative diabetic retinopathy / A. Kakehashi // Am. J. Ophthalmol. - 2002. - Vol. 134. - P. 763-765.

13. Aiello L. P. Sytemic considerations in the management of diabetic retinopathy / Aiello L. P., Cahill M. T., Wong J. S. // Am. J. Ophthalmol. - 2001. Vol. 132. - P. 760-776.

14. Rice T. A. Vitrectomy for diabetic rhegmatogenous retinal detachment/Rice T. A., Michels R. G. // Am. J. Ophthalmol. 1983. - Vol. 95. - P. 34-44.

15. UK Prospective Diabetes Study Group Tight blood pressure control and risk of macrovascular and microvascular complications in type 2 diabetes // UKPDS 38. BMJ. - Vol. 31. № 317. -P. 703-713.

16. Ho T. Vitrectomy in the management of diabetic eye disease / T. Ho, W. E. Smiddy, H. W. Flynn// Surv. Ophthalmol. - 1992.

- Vol. 37. - P. 190-202.

17. Prognostic indicators of success and failure in vitrectomy for diabetic retinopathy / J. T. Thompson, C. L. Auer, S. de Bustros // Ophthalmology. - 1986. - Vol. 93. - P. 290 -295.

18. Causes of severe visual loss in the early treatment diabetic retinopathy study: ETDRS report no. 24. Early Treatment Diabetic Retinopathy Study Research Group / Fong D. S., Ferris F. L., Davis M. D., Chew E. Y. // Am. J. Ophthalmol. 1999. - Vol. 127. - P. 137-141.

19. Visionrelated quality of life and visual function following vitrectomy for proliferative diabetic retinopathy / Okamoto F., Okamoto Y., Fukuda S. [et al.] // Am. J. Ophthalmol. -2008. Vol. 145. - P. 1031-1036.

20. Complications of vitreous surgery for diabetic retinopathy. II. Postoperative complications / Schachat A. P., Oyakawa R. T., Michels R. G., Rice T. A. // Ophthalmology. - 1983. - Vol. 90. - P. 522-530.
21. Complications of vitrectomy for non-clearing vitreous hemorrhage in diabetic patients / W. E. Benson, G. Brown, W. Tasman, J. A. McNamara // Ophthalmic. Surg. - 1988. - Vol. 19. - P. 862- 864

22. Predictive clinical features and outcomes of vitrectomy for proliferative diabetic retinopathy / D. Yorston, L. Wickham, S. Benson [et al.] // Br. J. Ophthalmol. 2008. - Vol. 92. - P. 365-368. 23. Complications of vitreous surgery for diabetic retinopathy. II. Postoperative complications / Schachat A. P., Oyakawa R. T., Michels R. G., Rice T. A. // Ophthalmology. - 1983. - Vol. 90. - P. 522- 530 .

24. Ishida M. Long-term results of vitrectomy for complications of proliferative diabetic retinopathy / M. Ishida, S. Takeuchi/ / Jpn. J. Ophthalmol. - 2002. - Vol. 46. - P. 117-122.

25. Yang C. M. Surgical treatment for diabetic retinopathy. Fiveyear experience/C. M. Yang// J. Formos. Med. Assoc. 1998. - Vol. 97. - P. 477- 484.

26. Visual outcome after vitrectomy for diabetic retinopathy. A five-year followup / M. Nakazawa, Y. Kimizuka, T. Watabe, [et al.] // Acta. Ophthalmol. (Copenh). - 1993. - Vol. 71. - P. 219 223.

27. Factors influencing the results of vitreous surgery in diabetic retinopathy. I. Iris rubeosis and/or active neovascularization at the fundus / J. Oldendoerp, M. Spitznas // Graefes. Arch. Clin. Exp. Ophthalmol. - 1989. - Vol. 227. - P. $1-8$.

28. Iris neovascularization after vitrectomy combined with phacoemulsifiction and intraocular lens implantation for proliferative diabetic retinopathy / K. Kadonosono, S. Matsumoto, E. Uchio [et al.] // Ophthalmic. Surg. Lasers. 2001. - Vol. 32. - P. 19 -24. 